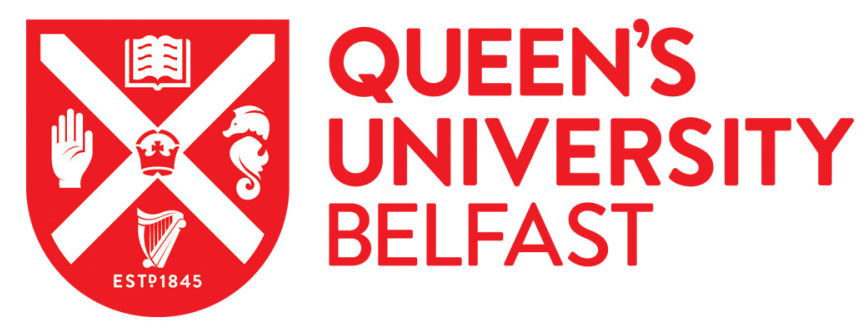

\title{
Financialization, urban governance and the planning system: Utilizing 'Development Viability' as a policy narrative for the liberalization of Ireland's Post-Crash Planning System
}

Waldron, R. (2019). Financialization, urban governance and the planning system: Utilizing 'Development Viability' as a policy narrative for the liberalization of Ireland's Post-Crash Planning System. International Journal of Urban and Regional Research, 43(4), 685-704. https://doi.org/10.1111/1468-2427.12789

Published in:

International Journal of Urban and Regional Research

Document Version:

Peer reviewed version

Queen's University Belfast - Research Portal:

Link to publication record in Queen's University Belfast Research Portal

Publisher rights

(C) 2019 Urban Research Publications Limited.

This work is made available online in accordance with the publisher's policies. Please refer to any applicable terms of use of the publisher.

\section{General rights}

Copyright for the publications made accessible via the Queen's University Belfast Research Portal is retained by the author(s) and / or other copyright owners and it is a condition of accessing these publications that users recognise and abide by the legal requirements associated with these rights.

Take down policy

The Research Portal is Queen's institutional repository that provides access to Queen's research output. Every effort has been made to ensure that content in the Research Portal does not infringe any person's rights, or applicable UK laws. If you discover content in the

Research Portal that you believe breaches copyright or violates any law, please contact openaccess@qub.ac.uk. 
Financialization, urban governance and the planning system: Utilizing 'Development Viability' as a policy narrative for the liberalization of Ireland's Post-Crash Planning System

\author{
Richard Waldron \\ School of Natural and Built Environment, Queen's University Belfast
}

\title{
Forthcoming in the International Journal of Urban and Regional Research
}

\begin{abstract}
Drawing upon the Irish case, this article explores the interaction between the financialized economy and the urban planning system. While considerable scholarship has examined the financialization of real estate, it remains unclear how planning systems are being repurposed to facilitate a finance-led regime of urban growth or how the 'real estate-financial complex' seeks to enact planning policy transformations that support its interests. This article explores how such actors have advanced the concept of 'financial viability of development' as a means of influencing the post-crisis re-regulation of Irish planning policy. This group has argued that housing construction in post-crash Ireland is unviable given the high development finance costs, onerous planning gain contributions and the lack of development certainty in the planning process. As such, housing construction has been at an alltime-low, leading to a new crisis in affordable housing provision. In response, a complicit State has further liberalised the planning system, introducing an array of policies that are evermore facilitative of development interests. Empirical findings, based on interviews with developers, lobbyists and planners, emphasise the importance of informal access to policymakers, the wielding of 'expert knowledge' and media management to co-opt the State into adopting financial viability within planning policymaking.
\end{abstract}

KEYWORDS: Financialization, Urban Political Economy, Ireland, Housing Crisis, Financial Viability

\subsection{Introduction}

Recent years have witnessed remarkable interest in the concept of financialization as scholars seek to understand the deepening role of finance in driving contemporary economic and social change (van der Zwan, 2014). Clearly, the financial crisis of 2008 helps explain this interest, which is framed as a crisis caused by reckless practices in the command centres of global finance and in the daily life of banks and their customers. Indeed, it appears that both the economy and daily life have become more financialized, meaning that "financial actors, markets, practices, measurements and narratives have become increasingly dominant at a variety of spatial scales within contemporary social and economic life, and this dominance is resulting in a structural transformation of economies, firms, states and households" (Aalbers, 2016, 2).

The concept of financialization has gained a particular traction within urban studies, where a series of research avenues explore the relationship between financialization and urbanization processes before and following the financial crisis. These include the financialization of housing (Aalbers, 2016); urban redevelopment (Kaika and Ruggiero, 2016); critical infrastructure (Allen and Pryke, 2013) and urban governance (Lake, 2015). Indeed, Walks (2013) contends that the increased articulation of financial risk within cities has transformed the built environment into an "urban debtscape," referring to the social and spatial outcomes and relationships produced through the use of credit in the city and their effects on prevailing political ideologies, subjectivities and government policies related to property ownership and development. 
Considering the deepening role played by finance in the real estate development process, it is somewhat surprising how little the discipline of urban planning has had to say about financialization (Siemiatycki and Siemiatycki, 2016). Indeed, a dearth in knowledge is evident with regard to how the planning system, legislation and policy are being influenced and shaped by financialization and the increasing penetration of the 'real estate-financial complex' (i.e. the term coined by Aalbers (2012) to capture the connections between the neoliberal State and the real estate and financial sectors) within the State's planning policymaking apparatus. It is unclear how finance and development actors have embedded financialization techniques, narratives and rationales into planning policy or how the State has shaped the organizational, policy and legislative frameworks of planning to facilitate financial capital seeking to speculatively access the built environment. This lacuna requires close attention on issues of path dependencies, the operation of entrenched interests and regulatory capture within the planning policymaking process.

This article seeks to understand how planning systems and policies are being redesigned to facilitate finance capital and how real estate-financial actors seek to enact planning policy transformations that support their positional interests. The article explores how an epistemic community of development and finance actors have applied the concept of 'financial viability' as a means of influencing the post-crisis re-regulation of Irish planning policy. This group has successfully argued that housing construction in Ireland after the crash is economically unviable given the high cost of development finance, onerous planning gain contributions, the lack of development certainty in the planning process and the imposition of regulations that have dampened property values and developer profitability. As such, housing construction has been at an all-time-low and has led to a new crisis in the provision of affordable housing supply. Thus, 'financial viability' has served as a productive narrative upon which a complicit State has enacted a radical programme of planning reform to facilitate the development sector.

Empirical findings, based on 42 semi-structured interviews with key planning and development stakeholders, emphasise the importance of informal access to policymakers and the wielding of expert knowledge and econometric data to create the political, social and technical pathways that support policies associated with developers' economic goals. More broadly, the findings suggest that the economic leverage of development interests is an important instrument in co-opting the State to support entrepreneurial urban policies and adopt financial logics and rationales within the planning policymaking system.

The article is structured as follows: section two briefly reviews the literature on the financialization of real estate and urban governance, pointing out its under-engagement with planning and the need for more agent-centred accounts of financialization to better understand the strategies and tactics used by real estate actors to shape policy outcomes that reflect their vested interests. Section three provides a detailed discussion of the methodological framework employed. Section 4 presents the empirical results and discusses how 'financial viability' has been defined and understood by the development lobby and the State and the nature of the obstacles to promoting housing supply. The article then explores the specific strategies and mechanisms by which the development lobby mobilised the viability narrative to ensure that their policy ideas and prescriptions were accepted among policymakers. Thereafter, a brief overview of the State's response to the viability issue is provided, highlighting how the viability narrative has shaped radical planning system change. Finally, some broad conclusions are drawn in relation to the results and the implications for theory and practice.

\subsection{Financialization, Neoliberal Urbanism and the Planning System}

To situate the discussion of 'financial viability' as a policy narrative for Irish planning reform, to substantiate its significance and assess its implications, this section draws together the literatures on financialization and neoliberal urban governance. Recently, financialization has become identified 
as a set of processes involving transformations at an economic, political and social level (van der Zwan, 2014). These include the growth of finance in response to declining profitability in the productive economy (Arrighi, 1994); the rise of 'shareholder value' and the financialization of corporations (Froud et al., 2007); and the growth of 'rentier' forms of financial accumulation (Moreno, 2014). These perspectives have produced important contributions on the nature of contemporary capitalism, including the nature of the growth of financial actors, markets and innovations (Krippner, 2011); the increasing embeddedness of financial risks within socio-economic life (Lapavitsas, 2012); and the political, social, economic and ontological impacts created by financialized capitalism (Langley, 2008).

This article, however, focuses on financialization within the urban development process and specifically the interactions between the 'real estate-financial complex' (Aalbers, 2012) and the neoliberal state regarding the development of urban planning policy. It is within this literature that the growth and dominance of financial actors and markets (Aalbers, 2016) intersects most clearly with the political restructuring ethos of neoliberalism, understood here as a class-based political project to strengthen the economic power of elite actors through the valorisation of the exchange value of land and property assets over their use values (Harvey, 2005). Indeed, if financialization represents the expansion and deepening influence of financial actors and markets, then it is neoliberalism that is the ideational framework that facilitates the policy, legal and regulatory adaptations necessary for the unfettered conversion of use-values into tradable exchange values (Ward and Swyngedouw, 2018). Such adaptations occur through a range of mechanisms including regulatory experimentation and capture (Brenner et al., 2010), but also through systems of 'fast policy' transfer that allow neoliberal policy proto-types to be deployed across territorial spaces by global networks of policy consultants, technocrats and lobbyists (Peck and Theodore, 2015).

In this regard, scholarship has increasingly focused on the relationship between financialization practices and urbanization processes, with particular attention paid to the interactions between land and property assets, financial actors and instruments and the neoliberal state (Halbert and Attuyer, 2016). Christophers (2017) interrogates the key role played by the State in enabling the financialization of its own public lands where technical valuation exercises and aggressive privatisation mechanisms were deployed to transfer vast tracts of the UK's public estate to investors who have subsequently exploited these lands as a financial asset. Drawing on Harvey's (2005) concept of 'accumulation by dispossession,' AlShehabi and Suroor (2016) examine how the Bahraini State utilised tactics of cronyism and expropriation to divert public lands to private investors and enable practices of fictitious capital formation. Regarding commercial property, recent scholarship has examined how property assets are increasingly transformed into liquid financial assets through a variety of financial innovations that can be traded globally by transnational investors and how such assets are acquired, not with a view to production or consumption, but simply to extract anticipated future revenue streams (van Loon and Aalbers, 2017, Wijburg, 2018). Indeed in Ireland, Byrne (2016b) and Waldron (2018) have highlighted the State's key role in enabling such practices through the sale of large urban investment portfolios by publicly-backed 'bad banks,' often at substantial cost to taxpayers.

Others have focused specifically on the financialization of housing, as new financial instruments and regulatory experimentation are used to transform spatially-fixed housing into highly liquid investment products (Gotham, 2009, Aalbers, 2016). Following the financial crisis, significant research focused on mortgaged homeownership and the manner by which homes and neighbourhoods became key sites for capital extraction (Crump et al., 2008, Waldron and Redmond, 2016). More recently, scholarship has broadened to other housing tenures to examine how financial innovations are opening new spaces and sectors for the penetration of finance post-crash. Some scholars have examined the expansion of US-based private equity funds into distressed European rental markets and how they target devalued assets with the view to extracting ever greater returns for investors (Janoschka and Alexandri, 2018, Beswick et al., 2016). Others examine how private rental housing has been transformed into a new asset class based on the bundling of rent receivables into new securities products that are sold on secondary exchanges (Fields, 2014). Still others consider the 
penetration of financial actors into the non-commodified housing sector, where public authorities are increasingly experimenting with new financing innovations in the bond market (Wainwright and Manville, 2017) or the creation of publicly-backed special purpose vehicles (Beswick and Penny, 2018) which serve to connect non-market housing providers to financial intermediaries in more direct forms.

More recently, research has examined the role of the State in mediating the financialization of urban governance and the manner by which government and public agencies are embracing the logics, narratives and practices of financial markets and actors in their policymaking (Ward and Swyngedouw, 2018, Aalbers, 2017). Here scholars have explored how urban policy is designed and implemented to facilitate financial investment in and through the built environment (Lake, 2015) and to meet wider public policy goals (Kirkpatrick, 2016). In Chicago, Weber (2010) examines the application of tax increment financing (TIF) strategies to demonstrate how the city government are active agents in incentivising the speculative, high-risk behaviours of developers. Ashton et al (2014) examine how Chicago's city government was instrumental in securing investor interest in, and control over, the city's parking meter infrastructure which was subsequently managed to promote investor returns. Similar strategies are noted regarding the financialization of water infrastructure, where financial management techniques have been applied to promote the investment potential of public infrastructure over and above the value for households (Allen and Pryke, 2013, Bresnihan, 2016). However, while such interventions yield short-term economic benefits, like substantial cash injections, they also burden the State with new liabilities, duties and exposures to risk in times of crisis (Anguelov et al., 2018).

Fiscal austerity and budgetary retrenchment, a key feature of neoliberal urbanism (Peck et al., 2013), is a primary factor influencing the financialization of urban governance. As local government becomes increasingly stretched through fiscal constraints and budgetary cutbacks under neoliberal rationalisation, the state increasingly looks to innovative through revenue raising exercises that are increasingly mediated through financialized means. Peck and Whiteside (2016) identify how such conditions have prompted a mutation from entrepreneurial to increasingly financialized forms of urban governance. They contend that while the underlying dynamics of neoliberal urbanism remain intact in the context of post-crisis austerity, the increasing reliance by city governments on financialized real estate markets has resulted in new mechanisms and strategies that have transformed the relationships between public and private actors, which are increasingly defined by new forms of financial disciplining, techno-fiscal management and the monetization of revenue streams through financial engineering. Similarly, Lake (2015) examines the subordination of urban policy to financial sector logics through the example of social impact bonds. These are a financial tool used to fund urban programmes that address 'subprime behaviours' in marginalized populations, such as prison recidivism, in order to reduce government expenditures and provide a return to investors. For Lake $(2015,76)$ such interventions represent the repurposing of urban public policy as a financial instrument, where the meeting of investors' expectations rather than addressing pressing social issues becomes the goal of urban policy.

However, despite the attention on the penetration of finance within urban governance, it is surprising that few scholars have considered the role of the planning system in shaping, and being shaped by, financial markets and actors (Siemiatycki and Siemiatycki, 2016, McAllister, 2017). As the regulator of development outcomes, planning has a clear role in directing the flow of interest-bearing capital in the built environment, yet few have considered planning's role within wider processes of financialized urban development. Kaika and Ruggerio (2016) consider how a non-financial corporate entity (Pirelli) restructured its depreciating industrial assets into a speculative real estate enterprise and examine the role that planning changes played in maximizing the development potential of these assets for investors. Drawing on cases from Milan and Dublin, both Savini and Aalbers (2016) and Byrne (2016a) consider how planning has been used in an instrumental fashion to facilitate financial investment by providing development flexibility and certainty for investors. However, while these cases valuably consider planning's implementation at the site-specific level to enhance investor 
profitability, they overlook how planning policy at a more macro-level has been repurposed to serve a finance-based economy. Put another way, how has the 'real estate-financial complex' embedded its rules, practices and narratives within planning policy to advance its positional interests?

According to Weber and O'Neill-Kohl (2013), such a knowledge gap partly stems from a tendency to privilege structural accounts of financialization over the role of agency and individual actors. Finance capital is often depicted in an omnipotent, uni-directional sense, imposing its will from above and only rarely considered are the networks of lobbyists, consultants and public sector advisors in determining how financialization is shaped through local social, political and economic relations (Weber, 2010). This concern echoes the interventions of Christophers (2015) and Ward and Swyngedouw (2018) who argue for a more in-depth treatment of the practical activity of finance and financial actors to better understand how financialization becomes operationalised from the ground up. In short, critical scholars must elaborate on how financial and real estate sector elites derive their power and influence, how they exert this influence in the political sphere and how State institutions have been co-opted to incorporate financial rationales and logics within public policymaking.

The literature on neoliberalism and its policy transfer mechanism can go some way towards bridging this gap, particularly regarding how the policymaking process has been captured by coalitions of vested interests and de-politicised as a technical exercise best left to technocrats and external experts (Harvey, 2005, Peck and Theodore, 2015). Fox-Rogers and Murphy (2013) elaborate on the informal strategies and tactics deployed by development interests to capture local planning policymaking and bypass the formal structures of the planning system, often based on their cultivation of close relationships with local authority management. In the UK, both Slater (2016) and Haughton and Allmendinger (2016) highlight the importance of examining the policy narratives shaped by freemarket think tanks and how they utilise industry-directed 'research' and fast channels of access to decision makers to embed their recommendations within the States policymaking apparatus. Often such market-oriented policies are communicated as 'commonsensical' orthodoxy in response to various economic crises to which the only answer is a further neoliberal fix (Brenner et al., 2010, McCann, 2011). Such responses are generally variants of neoliberal prescriptions instituted elsewhere that are re-packaged and transferred via 'fast' policy networks of trans-local consultants, think tanks and policy entrepreneurs (Peck and Theodore, 2015).

Urban scholars must pay closer attention to the manners and mechanisms by which real estate interests shape the policy tools available to government that enable the financialization of the built environment. This article addresses this concern by exploring how a highly organised development lobby have advanced a narrative regarding the 'financial viability' of residential development to support a re-drawing of the Irish planning system along financialized lines to further enhance development profitability. A series of hypotheses underpin this primary aim. Firstly, it is hypothesised that the State is facilitative of the real estate and financial sectors owing to their joint interest in promoting economic growth, because of ideological considerations and due to the revolving door that exists between the public and private sectors (Hofman and Aalbers, 2017). Secondly, such interests exert considerable influence over planning policymaking through formal and informal means and through their deployment of technical expertise and economic resources (FoxRogers and Murphy, 2013). Thirdly, planning interventions to improve development viability have done little to promote affordable housing supply, but rather have enhanced development profitability (Bowie, 2017). Such outcomes reinforce the economic power and influence of development-finance actors and further compound existing socio-economic inequalities in the urban environment.

\subsection{Methodology}

Following the financial crisis, Ireland has become a testbed for financial and property market restructuring and makes an interesting case to examine the interaction between the financialized economy and the urban planning system. As has been well documented, during the 2000 s Ireland 
experienced one of the most pronounced property market bubbles and busts in modern economic history (Waldron, 2016). While this bubble was primarily finance-led (Mercille and Murphy, 2015), there was also a catastrophic failure within the planning system to adequately regulate development expansion. Indeed, Ireland's planning system has been characterised as one that is entirely neoliberal in outlook, where legislative change and organisational restructuring embedded pro-development agendas within planning policy and planning departments, often with disastrous social and economic outcomes (Fox-Rogers and Murphy, 2013).

But Ireland makes for a compelling case in other ways, notably the extent to which the Irish State intervened in the development and banking sectors following the crash. Indeed, the State introduced a blanket guarantee of all bank liabilities ( $€ 485 \mathrm{bn}$ ) in 2008 and an extensive bank recapitalisation programme ( $€ 64 \mathrm{bn})$, thereby socialising private sector losses. In the property sector, the State established a 'bad bank,' the National Assets Management Agency (NAMA), to purchase $€ 74 \mathrm{bn}$ worth of distressed property loans from the banks and has since engaged in a massive reprivatisation of these assets by selling large portfolios of property, land and debt to a coterie of financial investors on highly favourable terms (Waldron, 2018, Byrne, 2016a). However, many of these opportunistic investors had little interest in developing the properties and lands they acquired, preferring instead to hoard assets in order to capitalise on a rebound in values during the recovery period. On the other hand, the domestic development sector was decimated by the crash, with many firms bankrupted or unable to access development finance from the domestic banks. The result has been a virtual cessation in residential development, where annual output fell by over $90 \%$ from 93,000 units in 2006 to just 8,300 units in 2013 (Housing Agency, 2017). This is despite the fact that housing demand has soared following the recession, particularly in Dublin where a minimum of 33,109 homes are required to be built between 2016 and 2020 (ibid).

This supply-demand imbalance is at the core of debate regarding the 'financial viability' of new residential construction in post-crash Ireland. The development sector and its lobbyists have successfully argued that housing construction is economically unviable given the onerous costs imposed by the planning system and other regulatory barriers (discussed below) which have constrained property values and developers' profit margins. Effectively, these interests are utilising the narrative of financial viability as Trojan horse to scapegoat the planning system and to argue for policy changes that suit their vested interests. The following section interrogates how this viability narrative has been constructed and mobilized and considers how a complicit State has enacted this narrative to initiate a radical reshaping of the planning system to enhance development profitability.

The project was operationalised through 42 interviews conducted during 2016/ 2017 with a purposive sample of development and policymaking interests (Table 1). A series of qualifying criteria were established to objectively identify suitable respondents. Interviews were only sought from largescale developers, Real Estate Investment Trusts and private real estate investors active in the residential market, particularly those affiliated with the industry's representative groups. These include the Construction Industry Federation (CIF), Property Industry Ireland (PII), the Irish Homebuilders Association (IHBA), the Urban Land Institute (ULI) and Society of Chartered Surveyors (SCSI). Consultants from the spheres of planning, economics, tax and corporate finance were approached as these actors advise developers on the viability of schemes, but also assist in making representations to policymakers and in many cases were also members of the lobby groups outlined above. Interviews were sought with representatives from the country's two professional planning bodies, the Irish Planning Institute and Royal Town Planning Institute, and local authority planners who could provide insight into the planning constraints raised by developers. Politicians from central and local government who sat on specific housing and planning policy committees were approached, as were senior civil servants with responsibilities in the areas of land management, forward planning, bank restructuring and development finance. 
Table 1 - Breakdown of Interviewees by Occupational Sector

\begin{tabular}{|l|cc|}
\hline Interviewee Sector & $\mathbf{n}$ & $\%$ \\
\hline Development & 13 & $31 \%$ \\
Consultant (Real Estate, Planning, Tax, Finance) & 12 & $29 \%$ \\
Planner & 5 & $12 \%$ \\
Politician & 2 & $5 \%$ \\
Civil Servant (Finance, Housing, Planning, NAMA) & 10 & $24 \%$ \\
Total & 42 & $100 \%$ \\
\hline
\end{tabular}

The interviews were semi-structured in nature and the research questions spanned a number of themes including the nature of the State's response to the property crash; the changing policy environment regarding finance, development and planning; barriers to new housing supply; the emergence of new funding approaches for development; and the role of industry in the development of planning policy. Given the commercially and politically sensitive nature of the questions, interviewees were informed that all discussions were strictly confidential and anonymous. The interviews were digitally recorded, transcribed and systematically coded to extract common themes emerging from the data, the results of which are presented in the following section.

\subsection{Results}

\subsection{Constructing a narrative regarding the 'financial viability' of residential supply}

It is widely believed by market interests and government that Ireland's housing supply crisis is the result of planning and financial barriers that are impacting the 'financial viability' of development. However, it is worth noting that 'financial viability' is not defined in any policy document or legislation. Rather, the term is loosely utilised to frame the debate around housing costs and identify barriers (and responses) to increasing housing supply. This lack of policy definition is problematic as viability has been narrowly conceived from a market-led view of maximising development profitability. Indeed, the majority of respondents equated viability with development profitability at a site-specific level, typically with developers achieving minimum margins of $15 \%$. Hence, from the outset the guiding principle behind policy responses to address viability has been the maximization of development profitability, as opposed to more substantive concerns regarding housing affordability, which the planning system would more typically be concerned with.

"...It's not actually defined...I think the policy in relation to viability is very vague" (Interviewee 1, Planning)

"...how residential viability works... There's a margin I need to make to make it viable for me to actually take on development risk." (Interviewee 5, Development)

The origins of the viability narrative lie within the organisational response of the Irish development sector to the financial crisis. The sector was politically tarnished by the crash and from 2009 found itself locked-out from the corridors of decision-making power. In reaction, a number of prominent developers, investors and consultants formed a series of representative groups to organise the industry's response to the crash and to advance their particular policy prescriptions in the recovery. New groups like Property Industry Ireland and the Urban Land Institute Ireland were formed in 2011/ 2012 to develop an industry directed evidence base to influence government policy in the planning, development and management of the urban environment. These groups were joined by traditional construction lobby groups, like the Construction Industry Federation, as well as by professional membership bodies, like the Society for Chartered Surveyors, and issue-specific groups like the Irish REITs Forum (Waldron, 2018). Through their memberships, these groups formed a 
loosely-knit 'epistemic community' of politically engaged real estate and finance professionals who share common assumptions about housing supply conditions and claim policy-relevant knowledge on the planning, financing and demand-side barriers that impact development viability (Haas, 1992).

These groups have consistently scapegoated the planning system as a barrier to housing supply along familiar lines. Firstly, they contend that government is too reliant on the private market for development levies and planning gain contributions to fund local infrastructure and social and affordable housing. Secondly, they argue that Ireland's building standards are overly generous and impose substantial costs that make development unviable. For example, the industry railed against Dublin City Council's 2007 apartment regulations, which mandated more generous apartment sizes than national standards (SCSI, 2011). These were introduced specifically because of the industry's poor record in building 'shoe box' apartments during the 1990s and to make high density, city-living more attractive to families (Howley, 2007). Thirdly, they have attacked the 'overly democratic' nature of Ireland's planning appeal system, which uniquely allows third parties appeal planning decisions to An Bord Pleanála, which is the national planning appeals board. This is a quasi-judicial body that makes decisions to grant or refuse appeals on planning decisions made by local authorities in Ireland (Grist, 2013). Developers argue that nearly all large housing developments are appealed, which leads to time delays and costs that are ultimately passed on to consumers. Fourthly, the industry has scapegoated planners' expertise, contending they lack understanding of the financial implications of their decisions.

Regarding development finance and taxation, the development lobby argue that the viability issue has been caused by a lack of low-cost development finance and high tax rates on development. Developers have been unable to access low-cost finance due to the highly restricted lending environment, where domestic banks will only fund $60 \%-65 \%$ of approved projects located in core locations. The remainder must be sourced through equity, which most developers do not have, or through mezzanine finance, which is prohibitively expensive. In response, the industry has sought the provision of State-backed, low-cost finance and the greater involvement of NAMA in providing development capital. On the taxation side, the industry railed against a 'Windfall Tax' of $80 \%$ on profits generated by land rezoning, which had been introduced in 2010 to curb the role played by speculation on land rezoning in driving up land values (Fox-Rogers and Murphy, 2013). They also lobbied for reductions in construction sector VAT rates and stamp duties, as well as for the introduction of new fiscal incentives on the sale of land and tax-friendly investment structures, like REITs, to attract international development capital (SCSI, 2013).

The development lobby have also made arguments for stimulating the demand-side of the viability equation, particularly for the loosening of mortgage lending restrictions that were introduced following the crash. As a result of profligate lending during the boom, Ireland experienced one of the highest mortgage default rates among advanced economies during the recession (Waldron, 2016). This prompted the Irish Central Bank to impose new lending restrictions from 2015 which restricted banks to lending mortgages with loan-to-value ratios (LTVs) of $80 \%$ for repeat purchasers, while first time buyers were limited to a $90 \%$ LTV on the first $€ 220,000$ of the purchase price and an $80 \%$ LTV ratio on the remainder. A loan-to-income ratio (LTI) of 3.5 was also applied for all borrowers. However, on the back of consistent industry opposition to the rules (Behaviour \& Attitudes, 2016, Construction Industry Federation, 2016), the Irish Central Bank made a number of changes and exemptions. The LTV rules for first time buyers were changed, allowing all borrowers draw down loans with an LTV of $90 \%$, while the $€ 220,000$ ceiling was removed. Additionally, the banks were permitted to breach the LTI and LTV caps in $20 \%$ of all new loans in a given year. Elsewhere, the industry lobbied for the introduction of a Help-to-Buy scheme ${ }^{1}$ as well as the introduction of Government guaranteed, lowcost mortgages for low-to-middle income households (Construction Industry Federation, 2015). The combination of these interventions led to a 58\% surge in first time buyers accessing the market between 2006 and 2017 and a 10\% growth rate in house prices over the same period (CSO, 2018). In

\footnotetext{
${ }^{1}$ The Help-to-Buy incentive offers First Time Buyers of newly built homes a refund of income tax and deposit interest retention tax paid over the previous four years up to a maximum of $€ 20,000$ subject to certain qualifying criteria.
} 
effect, as property prices have risen and made housing development more financially viable, developers have argued for financial supports and incentives to assist borrowers meet that rising cost, albeit these supports have only further strengthened house price inflation.

\subsection{Mobilizing the 'financial viability' narrative through the policymaking process}

Having identified the barriers affecting residential supply, the development lobby turned its attention to mobilizing the 'viability narrative' among Irish policymakers and politicians. Table 2 presents a summary of the main lobbying strategies and tactics utilised by the lobby groups to gain advantage in the policymaking process.

Table 2 - Lobbying strategies and tactics identified by interviewees

\begin{tabular}{|c|c|}
\hline Strategy & Lobbying Tactics \\
\hline $\begin{array}{l}\text { (1) Secure informal access to } \\
\text { the policymaking process }\end{array}$ & $\begin{array}{l}\text { a) Establish or draw on informal relations } \\
\text { b) Identify facilitative decision makers } \\
\text { c) Create industry-led policy fora } \\
\text { d) Exploit revolving door between public and private sectors }\end{array}$ \\
\hline $\begin{array}{l}\text { (2) Normalize the Viability } \\
\text { Narrative }\end{array}$ & $\begin{array}{l}\text { e) Ensure industry consistency and collaboration } \\
\text { f) Economic resources to produce requisite 'evidence base' } \\
\text { g) Media Management } \\
\text { h) Attuned to political realities }\end{array}$ \\
\hline $\begin{array}{l}\text { (3) Ensure policy changes } \\
\text { accord with industry view }\end{array}$ & $\begin{array}{l}\text { i) Production of reports, submissions \& amendments } \\
\text { j) Centralization of planning policy decision making } \\
\text { k) Allow officials take ownership of industry-devised recommendations } \\
\text { l) Utilise economic leverage }\end{array}$ \\
\hline
\end{tabular}

\subsubsection{Securing Informal Access to the Policymaking Process}

Two issues are worth highlighting regarding Ireland's planning policymaking process. Firstly, policy formulation occurs through the Department of Housing, Planning and Local Government, who issue directives and guidelines to local planning authorities in how they discharge their functions. However, the development of national guidance does not have a statutory consultation process (Grist, 2013). In some cases, the Department seek inputs from interested stakeholders, while in others they do not and in general the development of national planning policy is somewhat opaque. Secondly, emanating out of a series of corruption scandals from the 1990s, one of which involved land zoning (Government of Ireland, 2012), a new lobbying regulation regime was introduced in 2015. The Regulation of Lobbying Act defines lobbying as "communications about the initiation, development or modification of any public policy, the preparation of legislation, and the award of a any grant, loan or contract" and requires lobbyists to register their meetings with ministers and civil servants.

While many interviewees identified their participation in formal policy discussions, others highlighted how development interests seek more direct and informal access to policymakers and politicians. As highlighted below, the formal policymaking process is often initiated by more informal engagements with sectoral interests. Policy ideas are often absorbed from outside government and go through a process of informal consultation between officials and the proponents of policy change. This iterative process then leads to political discussion, where the political feasibility of changes is considered, often with buy-in from elected officials. Only at this point, once a clear policy direction has been established, will a policy proposal be opened up for more formal consultation. 
"...it starts with an idea somebody has or an inbound inquiry...senior officials within the Department attend and the people sponsoring the project...[to] present what they've learned...you then move into the political forum...you'd present it to the minister and his advisors [and]...get general buy in... then you go to consultation...[where] formal responses are submitted...you refine whatever you have...[And] get that approved by the minister" (Interviewee 21, Civil Servant)

The development lobby seek out facilitative policymakers who share a pro-development ethos and who have sufficient authority to implement recommendations. For example, in their efforts to establish an Irish REIT system, the Irish REIT Forum fostered interpersonal relationships with key advisors who were framing the Government's crisis response. Lobbyists utilised personal contacts with senior NAMA Executives to generate political support behind closed doors, while the Secretary General of the Department of Finance was also considered pre-disposed toward the Forum's aims (Waldron, 2018). Political contacts were leveraged, particularly a key advisor to the Fine Gael party, who incorporated a commitment to introducing a REIT system into the party's 2011 election manifesto. This political commitment negated any opposition to the REIT proposal from within the civil service. This highlights how policy prescriptions that have been developed through informal processes of influence can later become legitimised through a formal policy development process, masking the informal influence that has taken place behind closed doors.

"[NAMA Executive] and I were friendly already...[He] was very helpful because everything about property NAMA were consulted with...one of the tricks I learned long ago...persuade the parties to put it into their election manifesto...." (Interviewee 8, Development)

"The reason why you put it in [the manifesto] is because you then have leverage with the civil servants to force them to go and look at something..." (Interviewee 28, Civil Servant)

Accessibility to decision makers is inextricably linked to the economic power of individual groups and the connections that lobbyists foster with decision makers. Some civil servants and lobbyists specifically highlighted the closeness of their relationships, demonstrating how the regulation of lobbying can be easily side-stepped. Some interviewees felt that larger developers and their representatives were more likely to be facilitated in policy consultations based on the level of housing investment they could provide. Comparatively, advocacy groups and planning interests were considered not to get the same level of access afforded to commercial entities. Indeed, one planning representative highlighted how access to successive planning ministers had become more restricted and specifically discussed how little their organisation had been consulted by the then Minister (Simon Coveney) regarding the Government's policy response to the viability problem.

"I would obviously have personal contacts with them...So it's really, really close as it should be" (Interviewee 36, Civil Servant)

“...the lobbying register gives you some insight...it doesn't necessarily capture all of it...the more money you're bringing to the table in terms of development investment, the more you're going to be listened to..." (Interviewee 35, Politician)

"Not since Martin Cullen and Noel Dempsey, not since then have we actually [had meetings with Senior Minister]... We never met with Coveney.". (Interviewee 33, Planner)

Linked to the tactic of gaining informal access, sectoral interests have created their own policy consultation fora to influence decision makers, including public events and conferences, but also smaller, issue-specific workshops that are by invitation only. Such events allow industry build consensus around particular policy ideas, to conduct side-meetings with policymakers and educate them through exposure to industry-selected experts. The Urban Land Institute in particular utilises its

\footnotetext{
${ }^{2}$ Martin Cullen (2002-2004) and Noel Dempsey (1997-2002) are former Ministers for the Environment who had responsibility for planning policy as part of their Ministerial brief. Simon Conveney was Minister for Housing, Planning and Local Government between May 2016 and June 2017
} 
transnational knowledge network through such gatherings to explore the receptiveness of officials towards policy innovations and assuage opposition to specific proposals. Another lobbyist revealed the unusual access they were afforded to the planning Minister to set out the sector's concerns. They advocated for the creation of special fast-track application system for large housing developments, where the application would be centrally decided by An Bord Pleanala rather than by local planners, thereby negating the third party appeals system. Furthermore, this approach could allow developers circumvent local development plans, as An Bord Pleanala is not bound by the provisions of local plans in its decision making; effectively introducing a 'back door' approval system for large residential developments.

"...how you influence the process could be as much as you end up having a pint with somebody in a bar, or a side conversation at another event...there are opportunities in all of that" (Interviewee 35, Politician)

"...public sector people in other European countries were members of ULI...[they're] very helpful and influential in disarming and encouraging Irish officials" (Interviewee 30, Development).

"...we met him [Minister] four times over six or seven weeks for, amazing actually, from 8pm until midnight...they took it lock, stock and barrel and stuck it into the new housing bill." (Interviewee 4, Consultant)

The literature on regulatory capture highlights the importance to development actors of cultivating access to politicians, policy makers and other political insiders as a means of exercising influence (Walks, 2010, Jacobs, 2015). Indeed, some interviewees categorised the State's relationship with the development sector as a 'revolving door,' where employment opportunities can be provided for former politicians and political advisors in careers after politics. Some expressly identified how former advisors have been hired by private sector firms to exploit their access to decision-making networks, while others pointed to the access afforded to specific lobby groups on the basis of their hiring former politicians. However, the revolving door can also move in the other direction. Some interviewees highlighted how NAMA had been largely staffed by former employees of some of the largest property investment companies and banking institutions in Ireland, and that these individuals had been tasked with overseeing the agency's valuation and sales processes (Connolly, 2017). Indeed, some highlighted how a number of NAMA Executives had since returned to the private sector or established their own development companies, exploiting the market knowledge and relationships they gained while temporarily working as public servants.

"[real estate consultancy] have [named individual], the ex-advisor to [former planning Minister]...there's a lot of people there who have a lot of money and they will employ the right people to do it." (Interviewee 26, Consultant)

"I think the [Development Company] thing that's a kind of Ponzi scheme ... [former NAMA Executive] is cashing in on what he picked up in NAMA" (Interviewee 40, Development)

\subsubsection{Normalize the Viability Narrative}

The development lobby seek to normalize the discourse around viability to ensure their identification of the problems and proposed responses become accepted as matter of fact. Of crucial importance has been the lobby groups' organisational response, marshalling their economic resources and expert networks to create clear and consistent messaging regarding development barriers. The various lobby groups are intimately connected through their memberships, where individuals are often members of multiple organisations. The lobby groups often arrange specific sub-committees to consult their membership on key issues and to relay information to that membership in order to advance a consistent and unified message from industry to policymakers. One interviewee highlighted 
the importance of such membership networks, where the weight of numbers can elevate issues to the political level and provide legitimation for the proposals being advanced. Such "bulk volume representation" is particularly successful when combined with consistent, targeted messaging and awareness of the political realities as to what is achievable at any given point in time.

"It's a standard management technique. You build a support group round you, and the support group has tentacles going round..." (Interviewee 8, Development)

"Bulk volume representation... what separates a successful [proposal] is one that's well articulated and grounded in fact, and numbers, and has a thought through set of ideas" (Interviewee 37, Civil Servant)

A clear advantage of the development lobby is the level of economic resources they bring to the policymaking process, including financial resources, expertise and data, which they mobilize to produce the requisite 'evidence base' to buttress their lobbying activities. This evidence base takes the form of authoritive reports that are presented as irrefutable, independent and rigorous, even though this is often corporate research using selective literature reviews and case studies or draw upon questionable data, methodologies and analysis. Indeed, one influential report on the impacts of viability on residential supply was commissioned by the SCSI (2016) to counter the "information deficit" caused by a "lack of credible, market data on actual house building costs." Drawing on data from live construction projects in Dublin, the report 'demonstrated' that the cost of providing an average house was $€ 330,493$ but noted that $55 \%$ of this cost was imposed by the planning and taxation systems. In response, the report advocated for reduced development taxes; expanded State-backed development finance; reduced development levies and State-funded infrastructure provision to open up private sites.

However, interviewees highlighted serious shortcomings in the report's methodology, data and analysis. Firstly, data was only gathered from eight developments, although this was not revealed in the report's methodology, and there was no geographic or sectoral breakdown of the units provided. Secondly, developers are notoriously reticent to share commercially sensitive information and there is no discussion as to how data was gathered or verified, making it difficult to generalize the findings. Thirdly, on a number of variables the authors use proxy figures rather than actual, sitespecific values. For example, the report assumes a land cost per house of $€ 50,000$ but provides no justification for this figure. This raises questions about the accuracy of the findings regarding the extent of the viability gap, as well as the causative factors. Despite such shortcomings, the report was referenced as a key source informing the Government's (2016) recent strategy to address the housing crisis.

"...the Department is relying on the CIF or the SCSI...to trot out these reports which are adopting a vested interest...Average site $€ 50,000$. That's coming from the SCSI and plucked out of the air." (Interviewee 31, Consultant)

Through their resources, the development lobby can commission external consultants to conduct bespoke econometric and policy analyses to provide legitimation for their policy prescriptions. The usefulness of consultants is the appearance of independence and rigour that they provide, enabling the development lobby step-back from the public face of the policymaking process. The groups are aware of the political sensitivities of their lobbying and of the necessity for their proposals to appear neutral in order to manufacture legitimation. Or has Harvey (2001) describes, it is crucial for powerful capitalist actors to present their interests as the 'illusory general interest' and their ideas as the only universally valid ones. However, the independence of such advisors can be quite superficial and in cases the same consultants are hired on commercial contracts by developers and are highly unlikely to make recommendations that are contrary to a client's interests. 
"...sometimes we have to have a consultant involved because sometimes we find if we have [lobby group's] name on the front of it, you know... whereas this does give a level of independence" (Interviewee 19, Development)

"[Consultants] were brought over by [Developer]... an event was held by the Housing Agency, and the Department to talk about apartment standards...Now [Consultants] are employed by [Developer] to do the master plan in [Development Site]...they're not going to say something that will devalue your site." (Interviewee 26, Consultant)

The development lobby also use the media as a tool to normalise the discourse on the viability issue and as a secondary means of exerting political influence. The generation of media profile can also be encouraging to their membership, who ultimately support the lobby groups' funding base. The groups invest considerable resources into their communications strategies by funding dedicated communications teams and hiring public relations professionals. They strategically orient their work to the needs of journalists by producing briefing notes or their own opinion pieces for newspapers. Television and radio commentating are also prized for their public visibility. Interviewees highlighted their awareness of the needs of media organisations for responsiveness to particular policy issues and were capable of generating content at short notice. Media was also considered a tool to amplify their message and to communicate policy ideas to policymakers, such as the case of the fast-track planning proposal outlined below.

"...I've done 14 [articles], or thereabouts, episodes of Pat Kenny [radio show]...They ring me up all the time and they might give me like an hour's notice to appear..." (Interviewee 4, Consultant)

"I do a lot of it through the media because the State reads it...You could ask for meetings and they won't give them to you because they're exposed...but if you do it through the media, they'll phone you up... [Fast Track Planning] The first of it came out in an interview with Marion Finucane [radio show]...Then we got ministerial engagement... and we inputted hugely into it happening." (Interviewee 41, Development)

Political timing is also of key importance in the sector's lobbying, particularly the ability to identify the windows of opportunity within which they can change political discourse as to what policy reforms are feasible. This requires efforts to frame the nature of their particular issue, but also to develop proposals that chime with the political mood about what policy actions are possible (Haughton and Allmendinger, 2016). For example, some interviewees highlighted how the planning Minister was particularly open to the industry's recommendations following the general election of 2016, as housing was a pressing issue that the Minister had staked his political reputation on addressing. Furthermore, to be successful, the lobby groups must be knowledgeable in the day-to-day procedural operations of the policy-making process. They must be able to anticipate 'hot button' policy issues and produce analyses and recommendations quickly to coincide with such developments, while also knowing what is feasible within the political environment.

"...the Minister wants to be seen in the public area as taking action...So there's a political necessity driving the legislative timetable..." (Interviewee 35, Politician).

"...the good ones would even understand how the political system has changed. How the new Oireachtas ${ }^{3}$ is operating... That's actually very important." (Interviewee 36, Civil Servant)

\subsubsection{Ensure Policy Recommendations Accord with Industry's Perspective}

The lobbyists' final strategy is to ensure that any planning policy prescriptions advanced by the State accord with the industry's perspective. The lobby groups are keenly aware of the power

\footnotetext{
${ }^{3}$ The Irish Parliament
} 
distributions among policymakers, the formalistic requirements around consultation and procedures for submitting legislative amendments. Several interviewees highlighted how they would prepare draft bills and legislation in expectation that their recommendations would be adopted. Indeed, one lobbyist highlighted how they prepared the initial headings for the REIT legislation, which were then written up by Department officials before being returned to the lobbyists for amendments. Another political interviewee, reflecting on their previous NGO experience, outlined how lobbyists align their policy prescriptions with political parties by drafting their policy strategies and preparing their speeches and press releases. Well-resourced, corporate lobbyists are considered to utilise such techniques to an even greater degree. Such cases highlight how lobbyists exploit politicians' lack of technical expertise by translating complex and technical information into brief digestible notes.

"...I gave them all the headings. They wrote the first draft. I reviewed the first drafts... We described what we wanted in terms of the level of tax relief... [We] agreed a policy and then wrote up the law." (Interviewee 11, Consultant)

"...We tailored amendments that we wanted on the basis of what we thought individual parties would accept...[We] said look here's your party policy. Here's our amendment to this bill which is in line with that. We will write your speeches and press releases... more sophisticated players do this with government much more often." (Interviewee 35, Politician)

Through 2015, the development lobby were a vocal supporter for the creation of a dedicated Minister for Housing and Planning and the further centralization of policy decision-making in order to exert greater influence over policymakers and reduce democratic inputs into the planning system. Under new powers enacted in 2015, this new Minister is enabled to pass "Specific Planning Policy Requirements," which are new mandatory guidelines that effectively allow the Minister to override policies established by local government through the statutory development plan process. Controversially, these new powers were deployed in setting new apartment size standards which overrode the more generous standards that had been adopted by Dublin City Council, setting a worrying precedent in undermining local democracy in the planning system. Such practices highlight the complicity of the State in shaping new politico-institutional forms to facilitate development interests and raises questions about the degree of trust that can be placed in public representatives and not just those who lobby in their own interest.

"...the Minister can just fiat... the officials have given themselves phenomenal power to undermine local democratic control of housing standards and planning" (Interviewee 15, Planner)

The result of informal interactions between the State and developers tends to be that certain policy prescriptions generate a degree of implicit traction from decision makers before they reach the formal policymaking process. The lobby groups aim to change the tone of political discourse so that their policy ideas come to be seen as logical and appropriate. This works best if policy ideas are seen to have germinated from within the State's policy apparatus rather than from external influence (Hofman and Aalbers, 2017). The interviews demonstrate that informal interactions can lead to policymakers developing a sense of ownership over particular proposals given the level of input that they have in their drafting with industry. One initiator of the concept of 'fast track planning' joked how a Department official took credit for the formulation of the proposal, not only highlighting how open the Department is to accepting industry's recommendations but also how directly aligned the views of senior policymakers and development interests are.

"The guy told me in the Department he said 'You know I was instrumental.' I said it's the best thing you ever came up with." (Interviewee 41, Development)

The final tool deployed by the development lobby is to utilise the economic leverage they exact over the State in terms of generating residential supply, providing critical infrastructure and 
contributing to macro-economic growth. As Irish local authorities are reliant on development levies to fund services and infrastructure, they are particularly beholden to the industry's narratives regarding planning system barriers. Indeed, despite being owed more than $€ 350 \mathrm{~m}$ in unpaid levies from the property boom (Burke-Kennedy, 2013), the Dublin local authorities have reduced their levies by $25 \%$. However, such concessions directly result in reduced levels of service provision or displace these costs onto taxpayers. At the national level, construction is a major economic multiplier for the State and one that delivers high-paying jobs for manual skilled workers, which can be exploited by the development lobby to gain political traction for their proposals.

"You've got roads, drainage... urban regeneration... community/ culture, and open space... every euro that's collected [in levies], a portion of it goes to each one of the five... we introduced reductions of 25\% on the levy" (Interviewee 16, Planner)

"...they'll [politicians] only listen when it affects jobs..., jobs are now being lost to Ireland because of this." (Interviewee 41, Development)

\subsection{Responding to the 'Financial Viability' Narrative}

On the back of such lobbying, a complicit and neoliberal State has enacted a radical transformation of the Irish planning system through its recent housing strategy 'Rebuilding Ireland,' which asserts that planning needs to become "more responsive to the requirements and complexities around housing delivery" and must "support more effective delivery and viability of strategic housing development" (Government of Ireland, 2016). The strategy implements virtually all of the development sector's policy prescriptions, including the introduction of fast track planning; the further centralisation of planning functions; and revisions to development levies and planning gain. This strategy is complemented by further policy revisions to apartment regulations, allowing the development of ever smaller apartment units and new planning prescriptions to favour large-scale institutional investors in the delivery of build-to-rent developments (DoHPLG, 2018). Elsewhere, the State has incentivized investors by introducing a new fiscal treatment on the sale of development lands and assets, where investors pay no capital gain tax on the uplift in value on such assets provided they were held for seven years. The State has also utilised taxpayer funds to create new sources of cheap development finance and has privatized key elements of country's public infrastructure to generate loanable development capital (Mercille and Murphy, 2015). Additionally, the State earmarked 2,000 hectares of public lands to be offered to private developers at a reduced or no cost to provide up to 50,000 affordable homes. This scheme is further supported by a new $€ 200 \mathrm{~m}$ public fund to provide infrastructure to open up private development sites.

Through such actions the State has readily accepted the development sector's claims regarding viability constraints and the presumption that further liberalisation of the planning system, alongside greater development incentives, will lead to more affordable housing supply. Given the scale of these changes, it is remarkable how little evidence has been advanced to support such actions nor has the State subjected the analysis produced by industry to rigorous independent scrutiny. Furthermore, there is little to ensure that any cost savings gained will be passed through to to purchasers and renters in the form of lower sales prices or rents. As price takers, developers clearly have an incentive to use any cost efficiencies gained to further bolster their profit margins. Indeed, it would seem that the overly close relationship between policymakers and the development lobby has resulted in a process of 'decision-based evidence-making,' whereby corporate research and industry expertise are utilised as a veneer to justify policy decisions after the fact (Slater, 2016). Furthermore, this absence of verifiable data has been compounded by a lack of technical expertise and resources within the Department of Housing and Planning and by the ideological commitments of the Government with regard to the role of the private market in meeting housing needs. 
"Cost benefit analysis isn't, I haven't seen it on any of the policies that have come through yet from the Department. "(Interviewee 26, Consultant)

"...it's a really easy thing for the whole construction industry just blame planning which is a load of rubbish...there has to be a much more sort of robust analysis of where the problems lie." (Interviewee 31, Consultant)

"Coveney ended as he started believing...the principle role of government is to get the private sector to do the market better...that kind of technocratic language [i.e. financial viability] absolutely conceals the ideological policy choices. (Interviewee 35, Politician)

Finally, an important implication arising out of the development sector's framing of the viability issue has been the deflection of attention away from some of the more obvious causal factors. Principle among these has been the dramatic level of price inflation in the development land market since 2014, which has been fuelled by the State's capital gains tax exemption on land and the sale of very large urban investment portfolios by NAMA to a small number of international financial investors. The result been the creation of a new oligopoly in the Dublin land market, whereby investors have speculatively hoarded land and controlled its gradual release to market in order to keep values and profits high. In 2014 alone, development land values increased by an astonishing 32\% (SCSI, 2015). NAMA itself has revealed it sold lands with a capacity for 50,000 housing units since inception, yet just 3,700 units have been built or are under construction (O'Donovan, 2017). Furthermore, the singular focus on planning barriers and taxation costs deflects attention from the considerable levels of profit being realised by developers. The industry typically seeks minimum profit margins of $15 \%$, claiming that this is the minimum return level sought by financing institutions when assessing their funding decisions (Irish Independent, 2015). This 15\% profit level remains constant and if it is threatened, then it is the other inputs into the viability equation that must be adapted to compensate. Considering the influence that the industry's narrative around development viability has had, one can say that the Irish planning system is being reshaped to ensure that this minimum 15\% profitability level is maintained.

\subsection{Conclusions}

This article contributes to recent scholarship that explores the financialization of urban policy and governance (Anguelov et al., 2018), where policy is increasingly repurposed, redrawn and implemented as a financial instrument designed to facilitate investment in the built environment rather than as a practice aimed at addressing social or urban needs (Lake, 2015). While finance has long been a concern for urban political economy, it has often been conceptualised within a macrotheoretical sense, focused on capital switching dynamics or path dependent processes, or on the socio-spatial 'effects' of the expansion of finance within the built environment. More rarely considered are the particular generative processes, local conditions and meso-politics that support the financialization of the built environment (Peck and Whiteside, 2016). Where such issues are addressed, the focus has tended to be on the implementation of specific financial instruments or programmes, rather than the means and mechanisms by which urban policy has been influenced and shaped by specific constellations of real estate and financial actors. Indeed, the financialization literature has often under-played the role of human agency and particular capitalist actors in coordinating and shaping the flows of global financial capital into local real estate. When individual agents are discussed the focus tends to be on the principal politicians, regulatory czars and bank CEOs rather than the mid-level bureaucrats, consultants and lobbyists who shape the necessary institutional, policy, legislative, fiscal and legal frameworks that support financialization in practice. (Weber and O'Neill-Kohl, 2013). It is here that the literature on urban entrepreneurialism, with its longstanding focus on the operation of entrenched economic interests, practices of regulatory capture and 'fast policy' transfer (Harvey, 2005, Peck and Theodore, 2015) can elaborate on the manners and 
the mechanisms by which a complicit and neoliberal state has come to embrace the logics, narratives and practices of financial markets and actors within public policymaking.

To do so, this article explores how a highly organised and influential development lobby has constructed and mobilised a narrative regarding the 'financial viability' of development to scapegoat planning as the key barrier to generating residential housing supply and normalised the idea that planning must respond to market conditions affecting developers' profitability levels. The results raise important insights into the lobbying strategies of the 'real estate-financial complex' (Aalbers, 2012) and the tactics used to gain informal influence in planning policymaking. Firstly, by virtue of their economic power and the close alignment of their economic interests with the State, real estate and financial interests are readily accommodated in the policymaking process and are oftentimes able to sidestep formal policymaking structures that are designed to place a check on corporate influence. Secondly, real estate and financial sector interests deploy considerable human and economic resources to influence decision makers, including the production of corporate research, the establishment of industry-led policymaking fora and the utilization of industry expertise to legitimize their policy recommendations. Such practices provide an appearance of independence and rigour and present policy responses in a 'commonsensical' manner that often quickly morphs into accepted fact, even though such evidence is often based on selective interpretations of literature and data. Thirdly, the media serves as an important conduit for sectoral interests to shape and influence both public opinion and the actions of policy-makers, albeit such media interventions must also be accompanied by personal contact with decision makers to be effective. Fourthly, while industry exert considerable informal influence behind closed doors, the formal policymaking process can serve to conceal decisions already agreed at a higher level through informal channels of influence. Overall, the results highlight serious issues with regard to the democratic development of policy within the planning sphere and the role external interests play in shaping planning reforms.

The findings have a number of clear implications for planning policy and practice. Firstly, Ireland's system of lobbying regulation can be too easily side-stepped by corporate actors based on the informal relationships they cultivate with policymakers and the economic resources they can leverage in the policymaking process. Secondly, development interests are accommodated to a much greater degree in the policymaking process than other interested stakeholders like academics, NGOs and planning representatives. The counterweight to lobbying is public consultation and the State should prioritise greater public involvement in the formulation of national planning policy and develop a statutorily defined consultation process for doing so. Thirdly, planners must become more critically aware of the influence-wielding tactics of sectoral interests in planning policymaking and their role in normalizing the idea that planning must be ever-responsive to market concerns. Planners must be more assertive in resisting perpetual calls for planning reforms that often link social, economic and political challenges to claimed failings within the planning system. Scholars and practitioners must do more to expose the limitations of industry directed research used to justify policy adaptations and the questionable evidence bases and funding sources that underpin such work. Finally, if planning is to be reclaimed as a practice that can deliver socially just outcomes for society, it is imperative that planners negate the operation of entrenched interests in and through the planning system. Whether this can be achieved remains to be seen but tracing the influence of the 'real estate-financial complex' and exposing the structural relations that underpin this influence is a necessary first step in resisting the skewed vision of planning they present.

\section{Acknowledgements}

I would like to thank Declan Redmond, Mick Byrne and the three anonymous IJURR reviewers for their valuable comments on earlier drafts of this article. Needless to say, any errors or omissions remain my own. The research on which this article is based was funded by the Urban Studies Foundation through their Postdoctoral Research Fellowship scheme 2016-2019. 


\section{References}

AALBERS, M. B. (ed.) 2012. Subprime Cities: The Political Economy of Mortgage Markets West Sussex: WileyBlackwell.

AALBERS, M. B. 2016. The financialization of housing: A political economy approach, Oxon, UK, Routledge.

AALBERS, M. B. 2017. The variegated financialization of housing. International Journal of Urban and Regional Research, 41, 542-544.

ALLEN, J. \& PRYKE, M. 2013. Financialising household water: Thames Water, MEIF, and 'ring-fenced' politics. Cambridge Journal of Regions, Economy and Society, 6, 419-439.

ALSHEHABI, O. H. \& SUROOR, S. 2016. Unpacking “Accumulation By Dispossession”, "Fictitious Commodification", and "Fictitious Capital Formation": Tracing the Dynamics of Bahrain's Land Reclamation. Antipode, 48, 835-856.

ANGUELOV, D., LEITNER, H. \& SHEPPARD, E. 2018. Engineering the Financialization of Urban Entrpreneurialism: The JESSICA Urban Development Initiative in the European Union. International Journal of Urban and Regional Research, 42, 573-593.

ARRIGHI, G. 1994. The long twentieth century : money, power, and the origins of our times, London, Verso.

ASHTON, P., DOUSSARD, M. \& WEBER, R. 2014. Reconstituting the state: City powers and exposures in Chicago's infrastructure leases. Urban Studies, 53, 1384-1400.

BEHAVIOUR \& ATTITUDES 2016. Impact of Central Bank rules on the property market: Quantitative Research. Dublin: Behaviour \& Attitude.

BESWICK, J., ALEXANDRI, G., BYRNE, M., VIVES-MIRÓ, S., FIELDS, D., HODKINSON, S. \& JANOSCHKA, M. 2016. Speculating on London's housing future: The rise of global corporate landlords in 'post-crisis' urban landscapes. City, 20, 321-341.

BESWICK, J. \& PENNY, J. 2018. Demolishing the present to sell off the future? The emergence of 'financialized municipal entrepreneurialism'in London. International Journal of Urban and Regional Research, 42, 612-632.

BOWIE, D. 2017. Radical Solutions to the Housing Supply Crisis, Bristol, Policy Press.

BRENNER, N., PECK, J. \& THEODORE, N. 2010. Variegated neoliberalization: geographies, modalities, pathways. Global networks, 10, 182-222.

BRESNIHAN, P. 2016. The bio-financialization of Irish Water: New advances in the neoliberalization of vital services. Utilities Policy, 40, 115-124.

BURKE-KENNEDY, E. 2013. Councils owed $€ 750$ million in development levies [Online]. Dublin: The Irish Times. Available: http://www.irishtimes.com/news/environment/councils-owed-750-million-indevelopment-levies-1.1327535 [Accessed 20/08/2018].

BYRNE, M. 2016a. 'Asset Price Urbanism'and Financialization after the Crisis: Ireland's National Asset Management Agency. IJURR, 40, 31-45.

BYRNE, M. 2016b. Bad banks and the urban political economy of financialization: The resolution of financialreal estate crises and the co-constitution of urban space and finance. City, 20, 685-699.

CHRISTOPHERS, B. 2015. The limits to financialization. Dialogues in Human Geography, 5, 183-200.

CHRISTOPHERS, B. 2017. The State and Financialization of Public Land in the United Kingdom. Antipode, 49, 6285.

CONNOLLY, F. 2017. NAMA-LAND: The Inside Story of Ireland's Property Sell-Off and the Creation of a New Elite Dublin, Gill Books.

CONSTRUCTION INDUSTRY FEDERATION 2015. Budget 2015 Submission. Dublin: Construction Industry Federation.

CONSTRUCTION INDUSTRY FEDERATION 2016. Budget 2017 Submission. Dublin: Construction Industry Federation.

CRUMP, J., NEWMAN, K., BELSKY, E. S., ASHTON, P., KAPLAN, D. H., HAMMEL, D. J. \& WYLY, E. 2008. Cities destroyed (again) for cash: Forum on the U.S. foreclosure crisis. Urban Geography, 29, 745-784.

CSO. 2018. Residential Dwelling Property Transactions [Online]. Central Statistics Office. Available: https://www.cso.ie/px/pxeirestat/Statire/SelectVarVal/Define.asp?maintable=HPM02\&PLanguage=0 [Accessed 18/10/2018].

DOHPLG 2018. Sustainable Urban Housing: Design Standards for New Apartments Guidelines for Planning Authorities DRAFT UPDATE. Dublin: Department of Housing, Planning and Local Givernment.

FIELDS, D. 2014. The Rise of the Corporate Landlord: The Institutionalization of the Single-Family Rental Market and Potential Impacts on Renters. New York: Right to the City Alliance, Homes for All campaign. 
FOX-ROGERS, L. \& MURPHY, E. 2013. Informal strategies of power in the local planning system. Planning Theory, 13, 244-268.

FROUD, J., LEAVER, A. \& WILLIAMS, K. 2007. New actors in a financialised economy and the remaking of capitalism. New Political Economy, 12, 339-347.

GOTHAM, K. F. 2009. Creating Liquidity out of Spatial Fixity: The Secondary Circuit of Capital and the Subprime Mortgage Crisis. International Journal of Urban and Regional Research, 33, 355-371.

GOVERNMENT OF IRELAND 2012. The tribunal of enquiry into certain planning matters and payments. Dublin: Dublin Stationary Office.

GOVERNMENT OF IRELAND 2016. Rebuilding Ireland: Action Plan for Housing and Homelessness. Dublin.

GRIST, B. 2013. An introduction to Irish planning law, Institute of Public Administration.

HAAS, P. M. 1992. Introduction: epistemic communities and international policy coordination. International Organization, 46, 1-35.

HALBERT, L. \& ATTUYER, K. 2016. The financialisation of urban production: Conditions, mediations and transformations. Urban Studies, 53, 1347-1361.

HARVEY, D. 2001. Spaces of capital : towards a critical geography, Edinburgh, Edinburgh University Press.

HARVEY, D. 2005. A brief history of neoliberalism, Oxford, Oxford University Press.

HAUGHTON, G. \& ALLMENDINGER, P. 2016. Think tanks and the pressures for planning reform in England. Environment and Planning C: Government and Policy, 34, 1676-1692.

HOFMAN, A. \& AALBERS, M. B. 2017. Spaces of lobbying. Geography Compass, 11, e12309.

HOUSING AGENCY 2017. National Statement of Housing Supply and Demand 2016 and Outlook for 2017-18. Dublin: Housing Agency,.

HOWLEY, P. 2007. Sustainability versus liveability: an investigation into the implications of high-density living. PhD, School of Geography, Planning and Environmental Policy, University College Dublin.

IRISH INDEPENDENT. 2015. 'No company will build houses unless there's a margin there for them' [Online]. Dublin: IN\&M. Available: https://www.independent.ie/business/irish/no-company-will-build-housesunless-theres-a-margin-there-for-them-34170925.html [Accessed 21/08/2018].

JACOBS, K. 2015. The 'politics' of Australian housing: The role of lobbyists and their influence in shaping policy. Housing studies, 30, 694-710.

JANOSCHKA, M. \& ALEXANDRI, G. 2018. Who Loses and Who Wins in a Housing Crisis? Lessons from Spain and Greece for a Nuanced Understanding on Dispossession. Housing Policy Debate, 28, 117-134.

KAIKA, M. \& RUGGIERO, L. 2016. Land financialization as a 'lived'process: The transformation of Milan's Bicocca by Pirelli. European Urban and Regional Studies, 23, 3-22.

KIRKPATRICK, L. O. 2016. The New urban fiscal crisis: Finance, democracy, and municipal debt. Politics \& Society, 44, 45-80.

KRIPPNER, G. R. 2011. Capitalizing on Crisis: The Political Origins of the Rise of Finance Cambridge, MA, Harvard University Press.

LAKE, R. W. 2015. The financialization of urban policy in the age of Obama. Journal of Urban Affairs, 37, 75-78.

LANGLEY, P. 2008. The Everyday Life of Global Finance: Saving and Borrowing in Anglo-America: Saving and Borrowing in Anglo-America, OUP Oxford.

LAPAVITSAS, C. 2012. Financialisation in Crisis, Leiden, Brill.

MCALLISTER, P. 2017. The calculative turn in land value capture: Lessons from the English Planning System. Land Use Policy, 63, 122-129.

MCCANN, E. 2011. Urban policy mobilities and global circuits of knowledge: Toward a research agenda. Annals of the Association of American Geographers, 101, 107-130.

MERCILLE, J. \& MURPHY, E. 2015. Deepening Neoliberalism, Austerity, and Crisis: Europe's Treasure Ireland, Hampshire, UK, Palgrave MacMilan.

MORENO, L. 2014. The urban process under financialised capitalism. City, 18, 244-268.

O'DONOVAN, D. 2017. Nama chief makes dramatic accusations of land hoarding amid housing shortage crisis. Irish Independent, 01/06/2017.

PECK, J. \& THEODORE, N. 2015. Fast policy: Experimental statecraft at the thresholds of neoliberalism, University of Minnesota Press.

PECK, J., THEODORE, N. \& BRENNER, N. 2013. Neoliberal Urbanism Redux? International Journal of Urban and Regional Research, 37, 1091-1099.

PECK, J. \& WHITESIDE, H. 2016. Financializing Detroit. Economic Geography, 92, 235-268.

SAVINI, F. \& AALBERS, M. B. 2016. The de-contextualisation of land use planning through financialisation: Urban redevelopment in Milan. European Urban and Regional Studies, 23, 878-894. 
SCSI 2011. Impact of Dublin City Council Apartment Development Design Standards on Apartment Viability Dublin: SCSI.

SCSI 2013. Submission to the Department of Finance In advance of Budget 2013. Dublin: SCSI.

SCSI 2015. Annual Residential Property Review \& Outlook: The Report 2015. Dublin: Society of Chartered Surveyors Ireland.

SCSI 2016. The Real Cost of New House Delivery: Analysis of Real Market Data to Evaluate Viability and Affordability of New Housing Development. Dublin: SCSI.

SIEMIATYCKI, M. \& SIEMIATYCKI, E. 2016. The role of the scholar in times of crisis. European Planning Studies, 24, 1246-1261.

SLATER, T. 2016. Free market think tanks and the production of ignorance. In: SPRINGER, S., BIRCH, K. \& MACLEAVEY, J. (eds.) Handbook of Neoliberalism. Oxon, UK: Routledge.

VAN DER ZWAN, N. 2014. Making sense of financialization. Socio-Economic Review, 12, 99-129.

VAN LOON, J. \& AALBERS, M. B. 2017. How real estate became 'just another asset class': the financialization of the investment strategies of Dutch institutional investors. European Planning Studies, 25, 221-240.

WAINWRIGHT, T. \& MANVILLE, G. 2017. Financialization and the third sector: Innovation in social housing bond markets. Environment and Planning A, 49, 819-838.

WALDRON, R. 2016. The "unrevealed casualties" of the Irish mortgage crisis: Analysing the broader impacts of mortgage market financialisation. Geoforum, 69, 53-66.

WALDRON, R. 2018. Capitalizing on the State: The Political Economy of Real Estate Investment Trusts and the 'Resolution' of the Crisis. GeoForum, 90, 206-218.

WALDRON, R. \& REDMOND, D. 2016. Stress in Suburbia: Counting the Costs of Ireland's Property Crash and Mortgage Arrears Crisis. Tijdschrift voor economische en sociale geografie, 107, 484-501.

WALKS, A. 2010. Bailing out the wealthy: Responses to the financial crisis, ponzi neoliberalism, and the city. Human Geography, 3, 54-84.

WALKS, A. 2013. Mapping the Urban Debtscape: The Geography of Household Debt in Canadian Cities. Urban Geography, 34, 153-187.

WARD, C. \& SWYNGEDOUW, E. 2018. Neoliberalisation from the Ground Up: Insurgent Capital, Regional Struggle, and the Assetisation of Land. Antipode, 50, 1077-1097.

WEBER, R. 2010. Selling city futures: the financialization of urban redevelopment policy. Economic Geography, 86, 251-274.

WEBER, R. \& O'NEILL-KOHL, S. 2013. The Historical Roots of Tax Increment Financing, or How Real Estate Consultants Kept Urban Renewal Alive. Economic Development Quarterly, 27, 193-207.

WIJBURG, G. 2018. Privatised Keynesianism and the state-enhanced diversification of credit: the case of the French housing market. International Journal of Housing Policy, https://doi.org/10.1080/19491247.2017.1397926. 